\title{
Epigenetic alterations and occupational exposure to benzene, fibers, and heavy metals associated with tumor development (Review)
}

\author{
ROSSELLA SALEMI ${ }^{1}$, ANDREA MARCONI ${ }^{2}$, VALENTINA DI SALVATORE $^{1}$, SABRINA FRANCO $^{3}$, \\ VENERANDO RAPISARDA ${ }^{2}$ and MASSIMO LIBRA ${ }^{1}$ \\ ${ }^{1}$ Department of Biomedical and Biotechnological Sciences, Laboratory of Translational Oncology and \\ Functional Genomics, Section of General and Clinical Pathology and Oncology; ${ }^{2}$ Section of Occupational \\ Medicine, Department of Clinical and Experimental Medicine; ${ }^{3}$ Department of Medical, Surgical and \\ Advanced Technology Sciences 'G.F. Ingrassia', University of Catania, I-95123 Catania, Italy
}

Received December 30, 2016; Accepted February 16, 2017

DOI: $10.3892 / \mathrm{mmr} .2017 .6383$

\begin{abstract}
The chronic occupational exposure to contaminants and carcinogens leads to the development of cancer. Over the past decades, many carcinogens have been found in the occupational environment and their presence is often associated with an increased incidence of cancer. According to the International Agency for Research on Cancer (IARC), the majority of carcinogens are classified as 'probable' and 'possible' human carcinogens, while, direct evidence of carcinogenicity is provided in epidemiological and experimental studies. Additionally, accumulating evidence suggests that epigenetic alterations may be early indicators of genotoxic and non-genotoxic carcinogen exposure. In the present review, the relationship between exposures to benzene, mineral fibers, metals and epigenetic alterations are discussed as the most important cancer risk factors during work activities.
\end{abstract}

\section{Contents}

1. Introduction

2. Benzene

3. Natural fibers

4. Heavy metals

5. Conclusions

Correspondence to: Professor Massimo Libra, Department of Biomedical and Biotechnological Sciences, Laboratory of Translational Oncology and Functional Genomics, Section of General and Clinical Pathology and Oncology, University of Catania, Torre Biologica, Via Santa Sofia 97, I-95123 Catania, Italy E-mail:m.libra@unict.it

Key words: benzene, fibers, heavy metals, occupational exposure, epigenetics, cancer

\section{Introduction}

It is known that cancer arises from multiple factors. The identification of each factor, as the specific cause of cancer development, is the one of the main goals of cancer research. Many epidemiological studies have described the association between occupational exposures to carcinogens and cancer risk (1). Although, the incidence of cancer has decreased in the western world, an icreased incidence rate was observed among workers exposed to carcinogens (1-3). Since 2007 the International Agency for Research on Cancer (IARC) recognized 415 known or supposed cancerogens (2). Occupational activities associated to cancer risk may be caused by different factors; therefore, it is important to better identify every single factor implicated in this machinery to apply preventive guidelines and to better understand the pathogenic mechanism of cancer development. However, in some cases, there is a significant indication of an increased risk of development of various types of cancer with specific occupational exposure (4).

Several studies have shown that the risk of developing some cancers is associated with exposure to specific factors, such as non-ionizing radiation, 1,3-butadiene, benzene, natural fibers, air pollution, pesticides and solvents, polyaromatic hydrocarbons (PAHs), metal working fluids or mineral oil (5-11).

In addition to genetic alterations, a key role in neoplastic transformation is played by epigenetic alterations (12). For instance, it was demonstrated that chemically-induced carcinogenesis is associated with such epigenetic alterations including DNA methylation, changes of histones/chromatin structure and miRNA modifications (13-16).

Notably, several studies have shown that established occupational risk factors preferably bind to methylated DNA regions (17,18). Accordingly, epigenetic changes may be considered as a predictive biomarker of carcinogen exposure able to influence the genotoxic potential of the carcinogenetic agent (18).

This review summarizes the majority of the studies focusing on the relationship among epigenetic alterations, occupational risk factors and tumor development (Table I). The 
Table I. Occupational exposure to carcinogenic agents and epigenetic alterations.

\begin{tabular}{|c|c|c|c|c|}
\hline $\begin{array}{l}\text { Carcinogenic } \\
\text { agent }\end{array}$ & Uses and source & Cancer type & Epigenetic alterations & Author/(refs) \\
\hline Benzene & $\begin{array}{l}\text { Chemical industry, refineries, } \\
\text { gas stations, pharmaceuticals, } \\
\text { pesticides, plastic and dyes } \\
\text { and cigarette }\end{array}$ & NHL, AML & $\begin{array}{l}\text { Chromosomal alteration, } \\
\text { DNA hypomethylation } \\
\text { and hypermethylation, } \\
\text { histones modifications, } \\
\text { aberrant miRNA } \\
\text { expression }\end{array}$ & $\begin{array}{l}\text { Kalousová et al (24), } \\
\text { Subrahmanyam et al (25), } \\
\text { Zhang et al (26), } \\
\text { Costa et al (27), } \\
\text { Bollati et al (28), } \\
\text { Fenga et al (29), } \\
\text { Tabish et al (30), } \\
\text { Yu et al (34), } \\
\text { Bai et al (35), } \\
\text { Bai et al (36) }\end{array}$ \\
\hline $\begin{array}{l}\text { Asbestos } \\
\text { (fibrous } \\
\text { silicate } \\
\text { particles) }\end{array}$ & $\begin{array}{l}\text { Acoustical thermal } \\
\text { insulation, railway } \\
\text { construction and } \\
\text { building construction }\end{array}$ & Mesothelioma & $\begin{array}{l}\text { Promoter methylation, } \\
\text { miRNAs } \\
\text { downregulation }\end{array}$ & $\begin{array}{l}\text { Tsou et al (44), } \\
\text { Jones and Baylin (45), } \\
\text { Christensen et al (18), } \\
\text { Saito et al (46), } \\
\text { Lodygin et al (47), } \\
\text { Busacca et al (48), } \\
\text { Pass et al (49), } \\
\text { Kubo et al (50), } \\
\text { Christensen et al (51), }\end{array}$ \\
\hline Chromium & $\begin{array}{l}\text { Steel and end alloy } \\
\text { production, chrome } \\
\text { planting, dyes and } \\
\text { pigments manufacture }\end{array}$ & Lung cancer & DNA hypomethylation & $\begin{array}{l}\text { Takahashi et al (59), } \\
\text { Sun et al (60) }\end{array}$ \\
\hline Nickel & $\begin{array}{l}\text { Nickel planting and } \\
\text { battery production }\end{array}$ & $\begin{array}{l}\text { Lung cancer, } \\
\text { nasopharyngeal } \\
\text { carcinoma }\end{array}$ & $\begin{array}{l}\text { DNA hypomethylation } \\
\text { and hypermethylation, } \\
\text { Histone acetylation }\end{array}$ & $\begin{array}{l}\text { Karaczyn et al (66), } \\
\text { Golebiowski and Kasprzak (67), } \\
\text { Kowara et al (68), } \\
\text { Govindarajan et al (69), } \\
\text { Broday et al (70), } \\
\text { Chen et al (71) }\end{array}$ \\
\hline Arsenic & Pesticides & $\begin{array}{l}\text { Cancer of skin, } \\
\text { liver, urinary tract, } \\
\text { lung, colon and } \\
\text { hematopoietic } \\
\text { disorders }\end{array}$ & $\begin{array}{l}\text { DNA hypomethylation } \\
\text { and hypermethylation }\end{array}$ & $\begin{array}{l}\text { Baylin and Herman (76), } \\
\text { Zhao et al (77), } \\
\text { Chanda et al (78), } \\
\text { Cui et al (79) }\end{array}$ \\
\hline
\end{tabular}

comprension of this phenomenon will be helpful to prevent cancer development among workers.

\section{Benzene}

Benzene is an aromatic hydrocarbon that is widely used in various industrial contexts such as chemical industry, refineries, plants producing tires and lubricants. It is also used in the production of pharmaceuticals, pesticides, plastics and dyes. Occupational exposure to benzene is typically cutaneous or by inhalation. The general population may also be exposed to benzene because it is in the atmosphere, particularly in the areas of high vehicular traffic and in proximity to gas stations. Cigarette smokers are also exposed to benzene as it is contained in the cigarette. It is well known that exposure to benzene increases the risk of developing cancer in various human tissues and organs (2). In particular, it has been observed that its toxic effects may cause hematopoietic disorders such as non-Hodgkin's lymphoma, lymphocytic leukemia, acute myeloid leukemia (19-23). Chromosomal alterations have been suggested as the most common mechanisms of malignant transformation associated to benzene exposure (24-27). Most recently, epigenetic alterations, including DNA methylation, may also play a role in tumorigenesis $(28,29)$. For instance, several studies have indicated that exposure to benzene induces loss of global genomic methylation (28) and global DNA hypomethylation in human lymphoblastoid TK6 cells (30). Similar epigenetic alterations were found in hematopoietic malignancies, particularly in patients with acute myeloid leukemia in which 
other genetic alterations may occur $(31,32)$. On the other hand, further studies indicate that benzene induces DNA hypermethylation of the tumor suppressor genes p15 and p16 in benzene poisoning workers (33).

Yu et al observed $\mathrm{H} 4, \mathrm{H} 3, \mathrm{H} 3 \mathrm{~K} 4$ histones modifications in the promoter region of the topoisomerase II $\alpha$ (Topo II $\alpha$ ) in subjects exposed to benzene (34). Therefore, the involvement of Topo II $\alpha$ in benzene-induced hematotoxicity demonstrates the relationship between histone modifications and benzene exposure. Finally, association between benzene and aberrant miRNA expression was also reported in studies of benzene-exposed workers, indicating their association with benzene-induced hemotoxicity and leukemogenesis $(35,36)$.

\section{Natural fibers}

Various scientific evidence has clearly demonstrated the link between the occurrence of lung cancers and malignant mesothelioma (MM) during occupational and environmental exposure to asbestos $(37,38)$. However, information on molecular alterations in $\mathrm{MM}$, in patients exposed to mineral fibers, are not yet fully known or much less compared to other malignancies. Although the use of asbestos has been banned in major world nations for $>20$ years, the overall incidence of MM is estimated to occur in the year 2020, with a peak of incidence for this disease in the areas of occupational or environmental exposure to asbestos $(39,40)$.

Improved understanding of molecular genetic consequences of asbestos exposure may improve cancer prevention strategies of exposed people. To date, it is known that the asbestos fibers, are affected by macrophages, generate genotoxic reactive oxygen species that in turn are able to induce DNA damage leading to genetic alterations in MM (41-43). Furthermore, exposure to carcinogene fibers may cause epigenetic changes that reduce the activity of tumor suppressor genes in MM $(19,44,45)$. Accordingly, it was observed the activation of several proto-oncogenes associated with the downregulation of miRNA-127 and miRNA-34a (46,47). Indeed, several studies have indicated that aberrant expression of miRNAs play a role in MM development (48-50).

Moreover, other studies have shown that epigenetic changes significantly are associated with exposure to asbestos and significantly predict clinical outcome, discriminating the malignant phenotype from normal pleura (51).

\section{Heavy metals}

The carcinogenic potential of some metals is well known since the beginning of the 19th century. The economy expansion in the major industrialized countries has been accompanied by a parallel increase in consumption of metals which are now recognized as human carcinogens. Indeed, toxic metals such as chromium, nickel and arsenic are used extensively in the steel industry, the wood pressure-treated, to form alloys, for the production of coins and batteries, as catalysts for the production of carbon nanoparticles. Therefore, in highly industrialized countries the use of these metals results in increasing incidence of human cancers (2). Epigenetic mechanisms have been described in the pathogenesis of most common heavy metal-associated cancer types $(52,53)$.
Chromium. Occupational exposure to chromium is primarily via inhalation; in fact, the relationship between chromium and risk of lung, nasal, and especially respiratory cancer is well-known $(54,55)$. Strong mutagenic ability of chromium, due to its ability to enter the cells through the sulfate channels and to form stable chromium-DNA adducts, is also well-known $(56,57)$. Epidemiological studies have shown that cancer may occur after chromium exposure even at lower limits than those permitted, according to the current regulation (58).

Epigenetic mechanisms, such as hypermethylation of MLH1, have been suggested as potential mechanisms of malignant transformation during chromium exposure (59). Accordingly, the inactivation of MLH1 causes loss of functional mismatch repair (MMR) in chromate-exposed lung cancer (59).

In this regard, it was suggested that the increased dimethylation of histone H3 lysine 9 at the MLH1 promoter causes the downregulation of tumor suppressor genes, including MLH1 (60).

Nickel. Nickel and nickel compounds have been classified as human carcinogens accrding to IARC (2012) (61). The main route of human exposure to nickel is inhalation and its toxic effects on the respiratory system are well-known $(61,62)$. Exposure to various nickel compounds is associated with increased risks of lung cancer and nasal cancer (63) although for these cancer types the most common risk factor is tobacco smoking (64).

Several studies have demonstrated that the basis of nickel toxicity and carcinogenicity is in its ability to enter and accumulate into the cells (65). These events involve epigenetic changes such as DNA methylation as well as the activation or suppression of a number of transcription factors and histone acetylation $(66,67)$. In particular, in vivo and in vitro studies have shown that exposure to nickel may cause hypermethylation of the tumor suppressor gene p16 and its silencing $(68,69)$. The suppressive effects of nickel on histone $\mathrm{H} 4$ acetylation in both yeast and mammalian cells have also been demonstrated (70). Furthermore, previous studies have shown the loss of acetylation of H2A, H2B, H3 and H4 and the increase of $\mathrm{H} 3 \mathrm{~K} 9$ dimethylation in human lung cells exposed to soluble nickel $(67,71)$.

Arsenic. Occupational arsenic exposure occurs mainly in the workplace through inhalation. Pesticides may contain arsenic and their effects in chronic disorders have been recently summarized (72). Effects associated with arsenic exposure include cardiovascular and peripheral vascular disease, hematologic disorders and multiple cancers (cancers of the skin, lung, liver, urinary bladder, kidney and colon) $(72,73)$.

The oncogenic ability of arsenic is well-known for almost 30 years $(74,75)$. Over the last ten years, various scientific evidence has shown that epigenetic changes are important in arsenic carcinogenesis. Exposure to arsenic can induce DNA methylation changes such as hypomethylation and hypermethylation. These changes are typically observed in cancer. In vitro human kidney cells treated with arsenic were found both hypo- and hypermethylated (76). Similar data were 
observed in TRL-1215 rat liver epithelial cell line (77). Finally, other studies described a significant DNA hypermethylation of the promoter region of several genes including p53, p16, RASSF1A $(78,79)$.

\section{Conclusions}

A growing body of evidence exists on occupational risk factors and cancer development. Previous studies on the association between cancer and environmental risk factors are here summarized and discussed. A better understanding of the molecular mechanisms of cancer growth in this context allow us to identify novel procedures to reduce the risk factors during work activity.

Several cancer research studies focused on cancer risk assessment, cancer epidemiology and mutational changes induced by carcinogens. Over the past decade, research interest has also been focused on epigenetic alterations for their specificity and inheritance from generation to generation. Accordingly, such alterations can be considered an appropriate biomarker of carcinogen exposure.

Based on the above, epigenetic changes, here emphasized, seem to be the most common mechanisms of carcinogenesis. In fact, the number of studies devoted to understanding the epigenetic alterations caused by exposure to chemical carcinogens is rapidly increasing.

Consequently, the role of this epigenetic alteration in carcinogenesis, involving DNA hypomethylation or hypermethylation, histones/chromatin structure alterations, different expression of microRNA and genetic changes, are detailed. However, other mechanisms, including the involvement of the tumor microenvironment, may be involved in malignant transformation after exposure to carcinogens, such as the asbestos-like fibers (80). This is the case of mesothelioma in which an early marker of malignant transformation has been recently identified $(81,82)$.

Although, great effort has been dedicated on the knowledge of epigenetic mechanisms in carcinogenesis, further studies are always encouraged especially in the context of occupational medicine.

\section{Acknowledgements}

This study was supported in part by the Lega Italiana per la Lotta contro i Tumori (LILT).

\section{References}

1. Falzone L, Marconi A, Loreto C, Franco S, Spandidos DA and Libra M: Occupational exposure to carcinogens: Benzene, pesticides and fibers (Review). Mol Med Rep 14: 4467-4474, 2016.

2. Clapp RW, Jacobs MM and Loechler EL: Environmental and occupational causes of cancer: New evidence 2005-2007. Rev Environ Health 23: 1-37, 2008.

3. Boffetta $\mathrm{P}$ and Nyberg F: Contribution of environmental factors to cancer risk. Br Med Bull 68: 71-94, 2003.

4. Blair A, Marrett L and Beane Freeman L: Occupational cancer in developed countries. Environ Health 10 (Suppl 1): S9, 2011.

5. Hardell L, Carlberg M and Mild KH: Case-control study of the association between the use of cellular and cordless telephones and malignant brain tumors diagnosed during 2000-2003. Environ Res 100: 232-241, 2006.
6. Cheng H, Sathiakumar N, Graff J, Matthews R and Delzell E: 1,3-Butadiene and leukemia among synthetic rubber industry workers: Exposure-response relationships. Chem Biol Interact 166: 15-24, 2007.

7. Rybicki BA, Neslund-Dudas C, Nock NL, Schultz LR, Eklund L, Rosbolt J, Bock CH and Monaghan KG: Prostate cancer risk from occupational exposure to polycyclic aromatic hydrocarbons interacting with the GSTP1 Ile105Val polymorphism. Cancer Detect Prev 30: 412-422, 2006.

8. Agalliu I, Eisen EA, Kriebel D, Quinn MM and Wegman DH: A biological approach to characterizing exposure to metalworking fluids and risk of prostate cancer (United States). Cancer Causes Control 16: 323-331, 2005.

9. Kellen E, Zeegers M, Paulussen A, Vlietinck R, Vlem EV, Veulemans $\mathrm{H}$ and Buntinx F: Does occupational exposure to PAHs, diesel and aromatic amines interact with smoking and metabolic genetic polymorphisms to increase the risk on bladder cancer? The Belgian case control study on bladder cancer risk. Cancer Lett 245: 51-60, 2007.

10. Kellen E, Zeegers MP, Hond ED and Buntinx F: Blood cadmium may be associated with bladder carcinogenesis: The Belgian case-control study on bladder cancer. Cancer Detect Prev 31: 77-82, 2007.

11. Zhao Y, Krishnadasan A, Kennedy N, Morgenstern H and Ritz B: Estimated effects of solvents and mineral oils on cancer incidence and mortality in a cohort of aerospace workers. Am J Ind Med 48: 249-258, 2005

12. Sharma S, Kelly TK and Jones PA: Epigenetics in cancer. Carcinogenesis 31: 27-36, 2010.

13. Herceg Z, Lambert MP, van Veldhoven K, Demetriou C, Vineis P, Smith MT, Straif K and Wild CP: Towards incorporating epigenetic mechanisms into carcinogen identification and evaluation. Carcinogenesis 34: 1955-1967, 2013.

14. Smith MT, Guyton KZ, Gibbons CF, Fritz JM, Portier CJ, Rusyn I, DeMarini DM, Caldwell JC, Kavlock RJ, Lambert P, et al: Key characteristics of carcinogens as a basis for organizing data on mechanisms of carcinogenesis. Environ Health Perspect 124: 713-721, 2016.

15. Koturbash I, Beland FA and Pogribny IP: Role of epigenetic events in chemical carcinogenesis - A justification for incorporating epigenetic evaluations in cancer risk assessment. Toxicol Mech Methods 21: 289-297, 2011.

16. Pogribny IP and Rusyn I: Environmental toxicants, epigenetics, and cancer. Adv Exp Med Biol 754: 215-232, 2013.

17. Chen JX, Zheng Y, West M and Tang MS: Carcinogens preferentially bind at methylated $\mathrm{CpG}$ in the p53 mutational hot spots. Cancer Res 58: 2070-2075, 1998.

18. Christensen BC, Godleski JJ, Marsit CJ, Houseman EA, Lopez-Fagundo CY, Longacker JL, Bueno R, Sugarbaker DJ, Nelson HH and Kelsey KT: Asbestos exposure predicts cell cycle control gene promoter methylation in pleural mesothelioma. Carcinogenesis 29: 1555-1559, 2008.

19. Lan Q, Zhang L, Li G, Vermeulen R, Weinberg RS, Dosemeci M, Rappaport SM, Shen M, Alter BP, Wu Y, et al: Hematotoxicity in workers exposed to low levels of benzene. Science 306 : 1774-1776, 2004.

20. Collins JJ, Ireland B, Buckley CF and Shepperly D: Lymphohaematopoeitic cancer mortality among workers with benzene exposure. Occup Environ Med 60: 676-679, 2003.

21. Infante PF, Rinsky RA, Wagoner JK and Young RJ: Leukaemia in benzene workers. Lancet 2: 76-78, 1977.

22. Infante PF: Benzene exposure and multiple myeloma: A detailed meta-analysis of benzene cohort studies. Ann N Y Acad Sci 1076: 90-109, 2006.

23. Glass DC, Gray CN, Jolley DJ, Gibbons C, Sim MR, Fritschi L, Adams GG, Bisby JA and Manuell R: Leukemia risk associated with low-level benzene exposure. Epidemiology 14: 569-577, 2003.

24. Kalousová M, Zima T, Tesar V, Dusilová-Sulková S and Skrha J: Advanced glycoxidation end products in chronic diseases - clinical chemistry and genetic background (Review). Mutat Res 579: 37-46, 2005.

25. Subrahmanyam VV, Ross D, Eastmond DA and Smith MT: Potential role of free radicals in benzene-induced myelotoxicity and leukemia. Free Radic Biol Med 11: 495-515, 1991.

26. Zhang L, Eastmond DA and Smith MT: The nature of chromosomal aberrations detected in humans exposed to benzene. Crit Rev Toxicol 32: 1-42, 2002. 
27. Costa C, Ozcagli E, Gangemi S, Schembri F, Giambò F, Androutsopoulos V, Tsatsakis A and Fenga C: Molecular biomarkers of oxidative stress and role of dietary factors in gasoline station attendants. Food Chem Toxicol 90: 30-35, 2016.

28. Bollati V, Baccarelli A, Hou L, Bonzini M, Fustinoni S, Cavallo D, Byun HM, Jiang J, Marinelli B, Pesatori AC, et al: Changes in DNA methylation patterns in subjects exposed to low-dose benzene. Cancer Res 67: 876-880, 2007.

29. Fenga C, Gangemi S and Costa C: Benzene exposure is associated with epigenetic changes (Review). Mol Med Rep 13: 3401-3405, 2016

30. Tabish AM, Poels K, Hoet P and Godderis L: Epigenetic factors in cancer risk: Effect of chemical carcinogens on global DNA methylation pattern in human TK6 cells. PLoS One 7: e34674, 2012 .

31. Lübbert M, Oster W, Ludwig WD, Ganser A, Mertelsmann R and Herrmann F: A switch toward demethylation is associated with the expression of myeloperoxidase in acute myeloblastic and promyelocytic leukemias. Blood 80: 2066-2073, 1992.

32. McCubrey JA, Steelman LS, Franklin RA, Abrams SL, Chappell WH, Wong EW, Lehmann BD, Terrian DM, Basecke J, Stivala F, et al: Targeting the RAF/MEK/ERK, PI3K/AKT and p53 pathways in hematopoietic drug resistance. Adv Enzyme Regul 47: 64-103, 2007.

33. Xing C, Wang QF, Li B, Tian H, Ni Y, Yin S and Li G: Methylation and expression analysis of tumor suppressor genes p15 and p16 in benzene poisoning. Chem Biol Interact 184: 306-309, 2010.

34. Yu K, Shi YF, Yang KY, Zhuang Y, Zhu RH, Xu X and Cai G: Decreased topoisomerase II $\alpha$ expression and altered histone and regulatory factors of topoisomerase II $\alpha$ promoter in patients with chronic benzene poisoning. Toxicol Lett 203: 111-117, 2011.

35. Bai W, Chen Y, Yang J, Niu P, Tian L and Gao A: Aberrant miRNA profiles associated with chronic benzene poisoning. Exp Mol Pathol 96: 426-430, 2014

36. Bai W, Yang J, Yang G, Niu P, Tian L and Gao A: Long non-coding RNA NR 045623 and NR 028291 involved in benzene hematotoxicity in occupationally benzene-exposed workers. Exp Mol Pathol 96: 354-360, 2014

37. Morinaga K, Kishimoto T, Sakatani M, Akira M, Yokoyama K and Sera Y: Asbestos-related lung cancer and mesothelioma in Japan. Ind Health 39: 65-74, 2001.

38. Norbet C, Joseph A, Rossi SS, Bhalla S and Gutierrez FR Asbestos-related lung disease: A pictorial review. Curr Probl Diagn Radiol 44: 371-382, 2015

39. Tan C and Treasure T: Mesothelioma: Time to take stock. J R Soc Med 98: 455-458, 2005

40. Kukreja J, Jaklitsch MT, Wiener DC, Sugarbaker DJ, Burgers S and Baas P: Malignant pleural mesothelioma: Overview of the North American and European experience. Thorac Surg Clin 14 435-445, 2004.

41. Wang NS, Jaurand MC, Magne L, Kheuang L, Pinchon MC and Bignon J: The interactions between asbestos fibers and metaphase chromosomes of rat pleural mesothelial cells in culture. A scanning and transmission electron microscopic study. Am J Pathol 126: 343-349, 1987.

42. Xu A, Wu LJ, Santella RM and Hei TK: Role of oxyradicals in mutagenicity and DNA damage induced by crocidolite asbestos in mammalian cells. Cancer Res 59: 5922-5926, 1999.

43. Xu A, Huang X, Lien YC, Bao L, Yu Z and Hei TK: Genotoxic mechanisms of asbestos fibers: Role of extranuclear targets. Chem Res Toxicol 20: 724-733, 2007.

44. Tsou JA, Galler JS, Wali A, Ye W, Siegmund KD, Groshen S, Laird PW, Turla S, Koss MN, Pass HI, et al: DNA methylation profile of 28 potential marker loci in malignant mesothelioma. Lung Cancer 58: 220-230, 2007.

45. Jones PA and Baylin SB: The fundamental role of epigenetic events in cancer. Nat Rev Genet 3: 415-428, 2002.

46. Saito Y, Liang G, Egger G, Friedman JM, Chuang JC, Coetzee GA and Jones PA: Specific activation of microRNA-127 with downregulation of the proto-oncogene $B C L 6$ by chromatin-modifying drugs in human cancer cells. Cancer Cell 9: 435-443, 2006.

47. Lodygin D, Tarasov V, Epanchintsev A, Berking C, Knyazeva T, Körner H, Knyazev P, Diebold J and Hermeking H: Inactivation of miR-34a by aberrant $\mathrm{CpG}$ methylation in multiple types of cancer. Cell Cycle 7: 2591-2600, 2008.

48. Busacca S, Germano S, De Cecco L, Rinaldi M, Comoglio F, Favero F, Murer B, Mutti L, Pierotti M and Gaudino G MicroRNA signature of malignant mesothelioma with potential diagnostic and prognostic implications. Am J Respir Cell Mol Biol 42: 312-319, 2010.
49. Pass HI, Goparaju C, Ivanov S, Donington J, Carbone M, Hoshen M, Cohen D, Chajut A, Rosenwald S, Dan $\mathrm{H}$, et al: hsa-miR-29c* is linked to the prognosis of malignant pleural mesothelioma. Cancer Res 70: 1916-1924, 2010.

50. Kubo T, Toyooka S, Tsukuda K, Sakaguchi M, Fukazawa T, Soh J, Asano H, Ueno T, Muraoka T, Yamamoto H, et al: Epigenetic silencing of microRNA-34b/c plays an important role in the pathogenesis of malignant pleural mesothelioma. Clin Cancer Res 17: 4965-4974, 2011.

51. Christensen BC, Houseman EA, Godleski JJ, Marsit CJ, Longacker JL, Roelofs CR, Karagas MR, Wrensch MR, Yeh RF, Nelson HH, et al: Epigenetic profiles distinguish pleural mesothelioma from normal pleura and predict lung asbestos burden and clinical outcome. Cancer Res 69: 227-234, 2009.

52. Arita A and Costa M: Epigenetics in metal carcinogenesis: Nickel, arsenic, chromium and cadmium. Metallomics 1 222-228, 2009

53. Salnikow K and Zhitkovich A: Genetic and epigenetic mechanisms in metal carcinogenesis and cocarcinogenesis: Nickel, arsenic, and chromium. Chem Res Toxicol 21: 28-44, 2008.

54. Langård S: One hundred years of chromium and cancer: A review of epidemiological evidence and selected case reports. Am J Ind Med 17: 189-215, 1990.

55. Gibb HJ, Lees PS, Pinsky PF and Rooney BC: Lung cancer among workers in chromium chemical production. Am J Ind Med 38: 115-126, 2000

56. Nickens KP, Patierno SR and Ceryak S: Chromium genotoxicity: A double-edged sword. Chem Biol Interact 188: 276-288, 2010.

57. Beyersmann D: Effects of carcinogenic metals on gene expression. Toxicol Lett 127: 63-68, 2002

58. Park RM, Bena JF, Stayner LT, Smith RJ, Gibb HJ and Lees PS Hexavalent chromium and lung cancer in the chromate industry: A quantitative risk assessment. Risk Anal 24: 1099-1108, 2004.

59. Takahashi Y, Kondo K, Hirose T, Nakagawa H, Tsuyuguchi M, Hashimoto M, Sano T, Ochiai A and Monden Y: Microsatellite instability and protein expression of the DNA mismatch repair gene, $h M L H 1$, of lung cancer in chromate-exposed workers. Mol Carcinog 42: 150-158, 2005.

60. Sun H, Zhou X, Chen H, Li Q and Costa M: Modulation of histone methylation and $M L H 1$ gene silencing by hexavalent chromium. Toxicol Appl Pharmacol 237: 258-266, 2009.

61. International Agency for Research on Cancer: Nickel and nickel compounds, IARC monographs on the evaluation of carcinogenic risks to humans, volume $100 \mathrm{C}$. http://monographs. iarc.fr/ENG/Monographs/vol100C/mono100C-10.pdf. Accessed December 12, 2014.

62. Morgan LG and Usher V: Health problems associated with nickel refining and use. Ann Occup Hyg 38: 189-198, 1994.

63. Doll R, Morgan LG and Speizer FE: Cancers of the lung and nasal sinuses in nickel workers. Br J Cancer 24: 623-632, 1970

64. Polesel J, Franceschi S, Talamini R, Negri E, Barzan L, Montella M, Libra M, Vaccher E, Franchin G, La Vecchia C, et al: Tobacco smoking, alcohol drinking, and the risk of different histological types of nasopharyngeal cancer in a low-risk population. Oral Oncol 47: 541-545,2011.

65. Denkhaus E and Salnikow K: Nickel essentiality, toxicity, and carcinogenicity. Crit Rev Oncol Hematol 42: 35-56, 2002.

66. Karaczyn AA, Golebiowski $F$ and Kasprzak KS: Truncation, deamidation, and oxidation of histone $\mathrm{H} 2 \mathrm{~B}$ in cells cultured with nickel (II). Chem Res Toxicol 18: 1934-1942, 2005.

67. Golebiowski F and Kasprzak KS: Inhibition of core histones acetylation by carcinogenic nickel (II). Mol Cell Biochem 279: 133-139, 2005.

68. Kowara R, Salnikow K, Diwan BA, Bare RM, Waalkes MP and Kasprzak KS: Reduced Fhit protein expression in nickel-transformed mouse cells and in nickel-induced murine sarcomas. Mol Cell Biochem 255: 195-202, 2004

69. Govindarajan B, Klafter R, Miller MS, Mansur C, Mizesko M, Bai X, LaMontagne K Jr and Arbiser JL: Reactive oxygen-induced carcinogenesis causes hypermethylation of p16(Ink4a) and activation of MAP kinase. Mol Med 8: 1-8, 2002

70. Broday L, Peng W, Kuo MH, Salnikow K, Zoroddu M and Costa M: Nickel compounds are novel inhibitors of histone $\mathrm{H} 4$ acetylation. Cancer Res 60: 238-241, 2000.

71. Chen H, Ke Q, Kluz T, Yan Y and Costa M: Nickel ions increase histone $\mathrm{H} 3$ lysine 9 dimethylation and induce transgene silencing. Mol Cell Biol 26: 3728-3737, 2006

72. Gangemi S, Miozzi E, Teodoro M, Briguglio G, De Luca A, Alibrando C, Polito I and Libra M: Occupational exposure to pesticides as a possible risk factor for the development of chronic diseases in humans (Review). Mol Med Rep 14: 4475-4488, 2016. 
73. Tchounwou PB, Centeno JA and Patlolla AK: Arsenic toxicity, mutagenesis, and carcinogenesis - A health risk assessment and management approach. Mol Cell Biochem 255: 47-55, 2004.

74. Barrett JC, Lamb PW, Wang TC and Lee TC: Mechanisms of arsenic-induced cell transformation. Biol Trace Elem Res 21: 421-429, 1989.

75. Lee TC, Tanaka N, Lamb PW, Gilmer TM and Barrett JC: Induction of gene amplification by arsenic. Science 241: 79-81, 1988.

76. Baylin SB and Herman JG: DNA hypermethylation in tumorigenesis: Epigenetics joins genetics. Trends Genet 16: 168-174, 2000.

77. Zhao CQ, Young MR, Diwan BA, Coogan TP and Waalkes MP: Association of arsenic-induced malignant transformation with DNA hypomethylation and aberrant gene expression. Proc Natl Acad Sci USA 94: 10907-10912, 1997.

78. Chanda S, Dasgupta UB, Guhamazumder D, Gupta M, Chaudhuri U, Lahiri S, Das S, Ghosh N and Chatterjee D: DNA hypermethylation of promoter of gene p53 and p16 in arsenic-exposed people with and without malignancy. Toxicol Sci 89: 431-437, 2006.
79. Cui X, Wakai T, Shirai Y, Hatakeyama K and Hirano S: Chronic oral exposure to inorganic arsenate interferes with methylation status of $\mathrm{p} 16^{\mathrm{INK} 4 \mathrm{a}}$ and RASSF1A and induces lung cancer in $\mathrm{A} / \mathrm{J}$ mice. Toxicol Sci 91: 372-381, 2006.

80. Miozzi E, Rapisarda V, Marconi A, Costa C, Polito I, Spandidos DA, Libra M and Fenga C: Fluoro-edenite and carbon nanotubes: The health impact of 'asbestos-like' fibres. Exp Ther Med 11: 21-27, 2016

81. Rapisarda V, Salemi R, Marconi A, Loreto C, Graziano AC, Cardile V, Basile MS, Candido S, Falzone L, Spandidos DA, et al: Fluoro-edenite induces fibulin-3 overexpression in non-malignant human mesothelial cells. Oncol Lett 12: 3363-3367, 2016.

82. Rapisarda V, Ledda C, Migliore M, Salemi R, Musumeci A, Bracci M, Marconi A, Loreto C and Libra M: FBLN-3 as a biomarker of pleural plaques in workers occupationally exposed to carcinogenic fibers: A pilot study. Future Oncol 11 (Suppl): $35-37,2015$ 